\title{
Enhancement of solubility and dissolution rate of poorly water soluble raloxifene using microwave induced fusion method
}

\author{
Payal Hasmukhlal Patil", Veena Sailendra Belgamwar, Pratibha Ramratan Patil, \\ Sanjay Javerilal Surana
}

Department of Pharmaceutics, R.C. Patel Institute of Pharmaceutical Education and Research, Shirpur, Dhule, India

\begin{abstract}
The objective of the present work was to enhance the solubility and dissolution rate of the drug raloxifene $\mathrm{HCl}$ (RLX), which is poorly soluble in water. The solubility of RLX was observed to increase with increasing concentration of hydroxypropyl methylcellulose (HPMC E5 LV). The optimized ratio for preparing a solid dispersion (SD) of RLX with HPMC E5 LV using the microwave-induced fusion method was 1:5 w/w. Microwave energy was used to prepare SDs. HPMC E5 LV was used as a hydrophilic carrier to enhance the solubility and dissolution rate of RLX. After microwave treatment, the drug and hydrophilic polymer are fused together, and the drug is converted from the crystalline form into an amorphous form. This was confirmed through scanning electron microscopy (SEM), differential scanning calorimetry (DSC) and powder X-ray diffraction (PXRD) studies. These results suggested that the microwave method is a simple and efficient method of preparing SDs. The solubility and dissolution rate of the SDs were increased significantly compared with pure RLX due to the surfactant and wetting properties of HPMC E5 LV and the formation of molecular dispersions of the drug in HPMC E5 LV. It was concluded that the solubility and dissolution rate of RLX are increased significantly when an SD of the drug is prepared using the microwave-induced fusion method.
\end{abstract}

Uniterms: Raloxifene $\mathrm{HCl}$. Microwave-induced fusion method. Solid dispersion. Solubility enhancement. HPMC E5 LV.

O objetivo do presente trabalho foi aumentar a solubilidade e taxa de dissolução do cloridrato de raloxifeno (RLX), que é pouco solúvel em água. A solubilidade do RLX aumentou com o aumento da concentração de hidroxipropilmetilcelulose (HPMC E5 LV). A proporção otimizada para a preparação de uma dispersão sólida (DS) de RLX com HPMC E5 LV utilizando o método de fusão induzida por microondas foi de 1:5 (p/p). A energia do microondas foi usada para preparar DS. O HPMC E5 LV foi utilizado como veículo hidrofílico para aumentar a solubilidade e a taxa de dissolução de RLX. Após o tratamento por microondas, o polímero hidrofílico e o fármaco são fundidos em conjunto, sendo o fármaco convertido da forma cristalina para a amorfa. Confirmou-se por meio de microscopia eletrônica de varredura (MEV), calorimetria exploratória diferencial (DSC) e difração de raios X do pó (PXRD). Estes resultados sugerem que o método de microondas é simples e eficiente para a preparação de DS. A solubilidade e taxa de dissolução de DS foram aumentadas, significativamente, em comparação com RLX puro devido às propriedades tensoativas e umectantes de HPMC E5 LV e à formação de dispersões moleculares do fármaco em HPMC E5 LV. Concluiu-se que a solubilidade e a taxa de dissolução de RLX foram significativamente aumentadas quando a DS do fármaco é preparada utilizando o método de fusão induzida por microondas.

Unitermos: Cloridrato de raloxifeno. Método de fusão induzida por microondas. Dispersão sólida. Aumento da solubilidade. HPMC E5 LV.

\footnotetext{
*Correspondence: Ms. Payal H. Patil. Department of Pharmaceutics, R. C. Patel Institute of Pharmaceutical Education and Research, Near Karvand Naka, Shirpur-425405, Dhule - Maharashtra, India. E-mail: pharmapayal@gmail.com
} 


\section{INTRODUCTION}

Most newly formulated chemical entities have the disadvantage of low bioavailability because their aqueous solubility and dissolution rate are low (Belgamwar et al., 2011). Improving the water solubility of drugs is one of the most challenging aspects of formulation development (Serajuddin et al., 2000; Lin et al., 2004). The drug release profile must also be improved as this property is crucial in oral drug bioavailability, particularly for drugs with low gastrointestinal solubility and high permeability (Murali Mohan Babu et al., 2002; Karanth et al., 2006; Tekade et al., 2010). Many approaches have been used, such as micronization, solubilization, complexation with polymers, salt formation, using prodrugs and adding surfactants. However, all these methods suffer from certain limitations (Feeley et al., 1998). Amorphous systems exhibit significant solubility because of their extreme thermodynamic properties and lower energetic barriers compared with the crystalline forms (Pudipeddi et al., 2005; Belgamwar et al., 2011). The conversion of a drug from the crystalline state to an amorphous state is mainly achieved through two different methods: melting and solvent evaporation (Weuts et al., 2005; Nokhodchi et al., 2007). A novel approach based on the use of microwave irradiation has become a recognized method (Moneghini et al., 2008; Tekade et al., 2010; Shinde et al., 2010).

Microwave radiation consists of electromagnetic waves with frequencies between those of infrared and radio waves, in the range $0.3-300 \mathrm{GHz}$. It passes through materials and causes their molecules to oscillate, generating heat. Microwaves, with their ability to penetrate any substance, allow heat to be produced at any point in a sample at a given time (Kappe, 2004). In fact, microwave radiation offers several advantages such as rapid volumetric heating, no overheating at the surface, addressable heating, energy savings, higher yields and lower operating costs and involves much shorter preparation times (Zhou et al., 2003). It has been reported that microwave energy can influence the crystalline status of a drug and that the duration of exposure plays an important role in converting the drug to an amorphous state, thus improving its dissolution rate (Papadimitriou et al., 2008; Tekade et al., 2010; Kumar et al., 2011; Mohanachandran et al., 2010; Moneghini et al., 2008).

Raloxifene (marketed as Evista by Eli Lilly and Company) is an oral second-generation selective estrogen receptor modulator (SERM) used to prevent osteoporosis in postmenopausal women. It is 2-(4-hydroxyphenyl)$3-(\{4-[2-($ piperidin-1-yl)ethoxy] phenyl $\}$ carbonyl)-1benzothiophen-6-ol, which has estrogenic actions on bone and anti-estrogenic actions on the uterus and breast. It is a BCS class II drug, i.e. it has low solubility and high permeability. But the bioavailability of raloxifene is very low, only $2 \%$, due to a high first-pass metabolism in the liver by glucuronidation and enterohepatic cycling (Jha et al., 2011). So it would be advantageous to increase the solubility of the molecule. Raloxifene is available in $\mathrm{HCl}$ salt form as raloxifene (RLX; Rai et al., 2010; Jha et al., 2011). This drug is poorly absorbed from the gastrointestinal (GI) tract. Therefore it is important to enhance its aqueous solubility and dissolution rate compared with the oral solid dosage forms.

In this study, solid dispersions (SDs) of RLX in a low-viscosity grade of hydroxypropyl methylcellulose (HPMC E5 LV) were prepared using a microwave-induced fusion technique to enhance the solubility of the drug. The physical properties of the SDs prepared were characterized through differential scanning calorimetry (DSC), scanning electron microscopy (SEM), powder X-ray diffractometry (PXRD), Fourier transform infrared spectroscopy (FTIR) and solubility studies.

\section{MATERIAL AND METHOD}

\section{Material}

RLX was obtained as a gift sample from Zydus Cadila Healthcare Limited, Ahmedabad, India. HPMC E5 LV was gifted by Dow Chemical Company, Midland. Methanol and all other reagents used were of analytical grade.

\section{Method}

\section{Physical mixture}

Physical mixtures of RLX and HPMC E5 LV were prepared by mixing them in different ratios, from 1:1 to 1:6 $\mathrm{w} / \mathrm{w}$, simply using a mortar and pestle. Ratio optimization was carried out using a solubility determination method.

\section{Microwave induced fusion method}

Solid dispersions with different RLX:HPMC E5 $\mathrm{LV}$ ratios, from $1: 1$ to $1: 6 \mathrm{w} / \mathrm{w}$, were prepared using a microwave-induced fusion method. RLX and HPMC E5 $\mathrm{LV}$ were weighed in the ratio $1: 1$ and mixed gently for 5 minutes using a mortar and pestle. A fixed amount (i.e. $2 \mathrm{~g}$ ) of the mixture was subjected to microwave radiation for different durations $(3,4,5$ and 6 minutes $)$ at a constant power of $590 \mathrm{~W}$ in a microwave reactor (CATA-2R, Catalyst Systems, Pune, India). Similarly, mixtures of other ratios (from 1:2 to 1:6 w/w) were prepared. Only 
one beaker was placed at a time inside the microwave oven. The samples were exposed to microwave radiation for predetermined durations (3, 4, 5 and 6 minutes). Then the beakers containing the samples were maintained at room temperature for the samples to solidify. The solid dispersions were collected and placed in a desiccator for 24 hours, and then the product was pulverized using a mortar and pestle. The pulverized powders were passed through an $80 \#$ sieve.

\section{Characterization of solid dispersions}

- Drug content

SDs equivalent to $10 \mathrm{mg}$ of RLX were weighed and dissolved in sufficient amounts of $\mathrm{pH} 6.8$ buffer in a $100 \mathrm{~mL}$ volumetric flask, and the volume was made up to the mark with $\mathrm{pH} 6.8$ buffer. This solution was filtered using a $0.45 \mu \mathrm{m}$ membrane filter, and the concentration of the drug present in the solution was determined using a UV spectrophotometer at $287 \mathrm{~nm}$.

\section{- Solubility study}

The solubilities of RLX, the physical mixtures (PMs) and the SDs prepared using the microwaveinduced fusion method were determined in a $\mathrm{pH} 6.8$ phosphate buffer at $37^{\circ} \mathrm{C} \pm 0.5^{\circ} \mathrm{C}$. For each preparation, an equivalent of $10 \mathrm{mg}$ of drug was added to $10 \mathrm{~mL}$ of the buffer in a glass vial with a cap. The vials were placed in a glass shaker incubator and maintained at $37{ }^{\circ} \mathrm{C} \pm 0.5^{\circ} \mathrm{C}$ for 24 hours. Then the solutions were filtered through a $0.45 \mu \mathrm{m}$ membrane filter, and the filtrates were analyzed using a UV spectrophotometer at $287 \mathrm{~nm}$.

- In vitro drug dissolution study

The dissolution rates of RLX and different SDs were determined in $900 \mathrm{~mL}$ of $\mathrm{pH} 6.8$ buffer at $37{ }^{\circ} \mathrm{C} \pm 0.5^{\circ} \mathrm{C}$ with a stirrer rotation speed of $75 \mathrm{rpm}$ using the USP Dissolution Apparatus II (paddle type). Aliquots (5 mL) of the sample were withdrawn at 5, 10, 15, 30, 45, 60, 90, 105 and 120 minutes using a pipette. The samples were suitably diluted and assayed spectrophotometrically at $287 \mathrm{~nm}$. Each dissolution rate test was repeated three times. The dissolution efficiency (DE) was selected, as a model-independent parameter, to evaluate the dissolution rate of RLX. The DE is defined as the area under the dissolution curve up to time $t$, expressed as a percentage of the area of the rectangle described by $100 \%$ dissolution in the same time. $\mathrm{DE}_{60}$ and $\mathrm{DE}_{120}$ were calculated from the dissolution data and used for comparison.

- Fourier-transformed infrared spectroscopic study RLX, HPMC E5 LV, the PMs and the SDs were mixed separately with IR-grade $\mathrm{KBr}$ in the ratio $1: 100$, and corresponding pellets were prepared by applying a pressure of 10 metric tons in a hydraulic press. The pellets were then scanned over a range of $4000-400 \mathrm{~cm}^{-1}$ in an FTIR instrument (8400 S Shimadzu).

- Differential scanning calorimetry study

DSC curves of RLX, HPMC E5 LV, the PMs and the SDs were obtained using a differential scanning calorimeter (Mettler Toledo DSC 1 Star System, Zurich, Switzerland) at heating rate of $10{ }^{\circ} \mathrm{C} /$ minute from $40{ }^{\circ} \mathrm{C}$ to $340^{\circ} \mathrm{C}$ in a nitrogen atmosphere.

- Powder X-ray diffraction study

PXRD patterns of RLX, HPMC E5 LV, the PMs and the SDs were recorded using a diffractogram (Bruker AXS, D8 Advance, Germany) and $\mathrm{Cu}-\mathrm{K} \alpha$ radiation. The diffractograms were run at a scanning speed of $2 \%$ minute and a chart speed of $2^{\circ} / 2 \mathrm{~cm}$ per $2 \theta$.

- Scanning electron microscopy study

SEM photographs of RLX and the SDs were obtained using a scanning electron microscope (JSM 6390LV, JEOL Model, Japan) with a $10-\mathrm{kV}$ accelerating voltage.

- Statistical evaluation

All results were expressed as the mean \pm S.D. Differences between two related parameters were considered statistically significant for $P$-values of 0.05 or less. The ratio optimization, solubility determination and dissolution efficiency results were analyzed using one way ANOVA.

\section{RESULTS AND DISCUSSION}

\section{Drug content}

The drug content of the SDs prepared is given in Table IV. The drug content of the SDs was found to be $91.89 \% \pm 0.30 \%$.

\section{Solubility study}

The ratio optimization data are shown in Table I. These data suggest that the solubility is significantly enhanced in the case of the SD with an RLX:HPMC E5 $\mathrm{LV}$ ratio of $1: 5$. Changing the ratio to $1: 6$ produced no significant enhancement in solubility. Therefore, it was concluded that the 1:5 ratio is optimal and was used for further studies. The solubility data for RLX, the PMs and 
the SDs are provided in Table II. These data show that HPMC E5 LV significantly enhanced the solubility of RLX in SDs compared with the solubility of RLX.

TABLE I - Ratio Optimization of Raloxifene $\mathrm{HCl}$ to HPMC E5 LV

\begin{tabular}{cc}
\hline $\begin{array}{c}\text { Drug: Polymer Ratio } \\
\text { RLX:HPMC E5 LV }\end{array}$ & $\begin{array}{c}\text { Solubility } \\
(\mathrm{mg} / \mathrm{mL})\end{array}$ \\
\hline $1: 1$ & $0.994 \pm 0.05$ \\
$1: 2$ & $1.328 \pm 0.61$ \\
$1: 3$ & $2.165 \pm 0.18$ \\
$1: 4$ & $4.740 \pm 0.87^{*}$ \\
$1: 5$ & $7.081 \pm 0.86^{*}$ \\
$1: 6$ & $7.961 \pm 0.87$ \\
\hline
\end{tabular}

All values are Mean \pm S.D, $n=3, *$ Significant

TABLE II - Solubility study of Raloxifene $\mathrm{HCl}$, physical mixture and solid dispersion

\begin{tabular}{cc}
\hline Product & Solubility $(\mathbf{m g} / \mathbf{m L})$ \\
\hline Raloxifene HCl & $0.977 \pm 0.19$ \\
Physical mixture & $7.081 \pm 1.02^{*}$ \\
Solid dispersion & $17.237 \pm 1.58^{*}$ \\
\hline
\end{tabular}

All values are Mean \pm S.D. * Significant

\section{In vitro drug dissolution study}

In vitro dissolution profiles of RLX and the SD prepared using the microwave-induced fusion method with an exposure time of 6 minutes are shown in Figure 1. The dissolution profiles of RLX and SDs prepared with exposure times of 3, 4, 5 and 6 minutes are shown in Figure 2. From the dissolution profiles it is seen that the microwave-induced fusion technique improves the dissolution rate of RLX to a great extent. The dissolution efficiencies of SDs at 60 and 120 minutes are presented in
Table III. The maximum enhancement in the dissolution rate is $65.42 \% \pm 0.39 \%$, at 120 minutes.

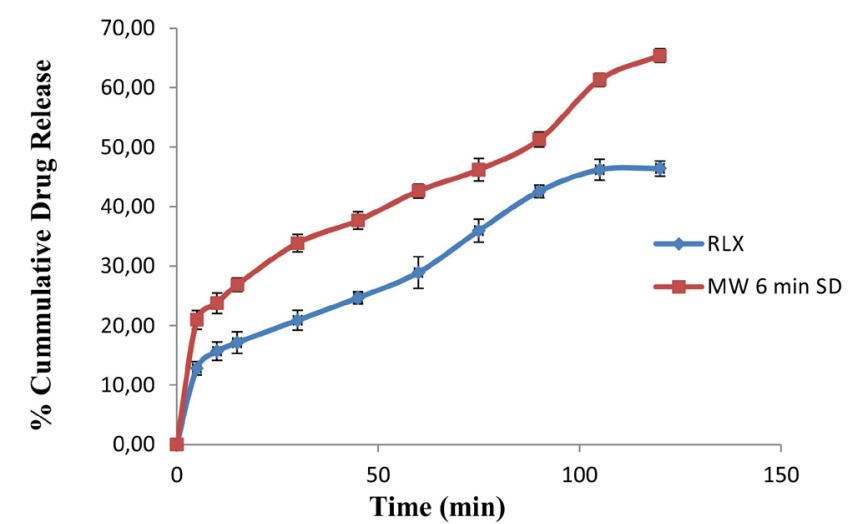

FIGURE 1 - Dissolution profiles of raloxifene $\mathrm{HCl}$ and solid dispersions prepared by microwave induced fusion methods. (a) RLX, Raloxifene $\mathrm{HCl}$ (b) MW 6 min SD, solid dispersions prepared by the microwave induced fusion method with an exposure time of $6 \mathrm{~min}$.

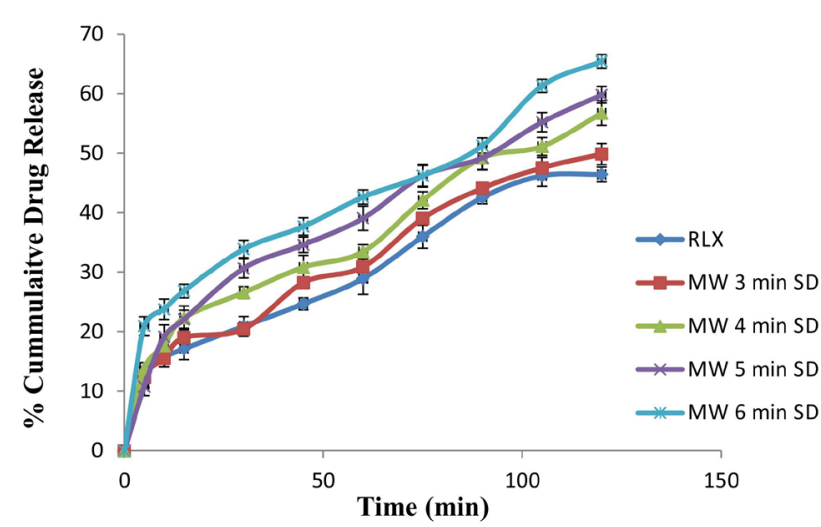

FIGURE 2 - Dissolution profiles of raloxifene $\mathrm{HCl}$ and solid dispersions prepared by the microwave induced fusion method. RLX, Raloxifene HCl. Solid dispersions (SD) were prepared by the microwave (MW) induced fusion method with different exposure times $(3,4,5$ and $6 \mathrm{~min})$.

TABLE III - Dissolution efficiency of RLX and solid dispersions

\begin{tabular}{lcc}
\hline \multirow{2}{*}{ Product } & \multicolumn{2}{c}{ Dissolution Efficiency } \\
\cline { 2 - 3 } & $\mathrm{DE}_{60}$ & $\mathrm{DE}_{120}$ \\
\hline Raloxifene HCl (RLX) & $28.92 \pm 1.53$ & $46.42 \pm 2.11$ \\
Solid dispersion: MW 3min & $30.87 \pm 1.46$ & $49.84 \pm 2.29$ \\
Solid dispersion: MW 4min & $33.42 \pm 2.92$ & $56.72 \pm 2.52^{*}$ \\
Solid dispersion: MW 5min & $39.04 \pm 2.71^{*}$ & $59.80 \pm 1.25^{*}$ \\
Solid dispersion: MW 6min & $42.61 \pm 1.69^{*}$ & $65.42 \pm 2.68^{*}$ \\
\hline
\end{tabular}

Solid dispersions prepared by the microwave (MW) induced fusion method had exposure times of 3, 4, 5 or 6 min. All values are Mean \pm S.D, $\mathrm{n}=3$. *Significant 


\section{FTIR spectroscopic study}

FTIR spectra of RLX, HPMC E5 LV, a PM and an $\mathrm{SD}$ are presented in Figure 3. The spectra of RLX exhibit characteristic peaks at $1642.44 \mathrm{~cm}^{-1}(\mathrm{C}=\mathrm{O}$ stretching $)$, $1596.15 \mathrm{~cm}^{-1}$ (-C-O-C-stretching), $1466.91 \mathrm{~cm}^{-1}$ (-Sbenzothiofuron), and $905.61 \mathrm{~cm}^{-1}$ (benzene ring). Any interaction among a drug and excipients results in the shifting of the peaks of the functional groups in the IR spectra. But the peaks of the functional groups of RLX were retained well in the PM as well as in the SD. These results indicate that no interaction occurred between the drug and excipients.

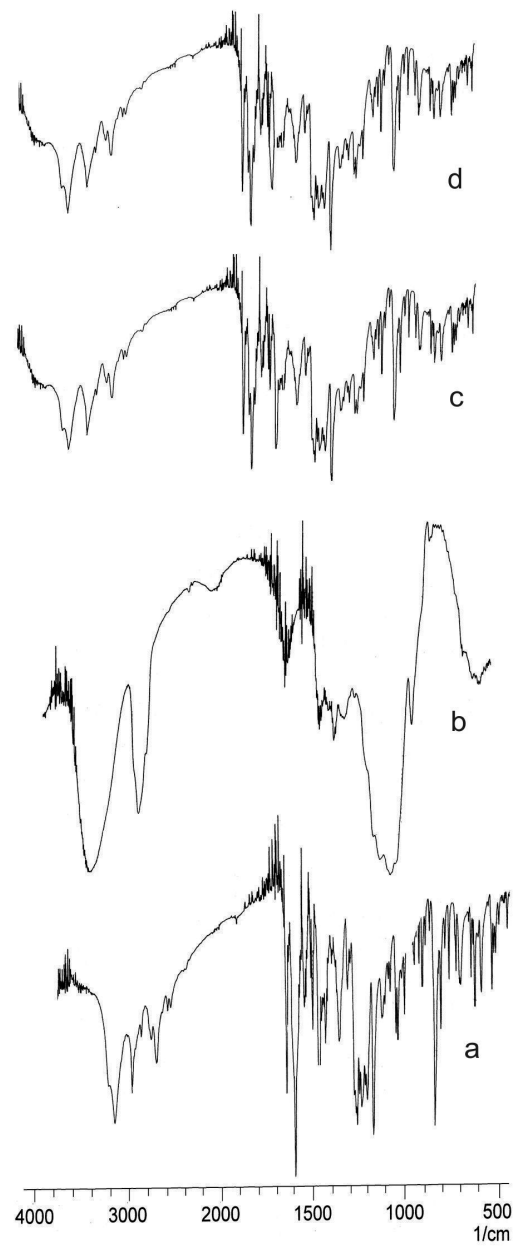

FIGURE 3 - Fourier transformed infrared spectra of (a) Raloxifene $\mathrm{HCl}$, (b) HPMC E5 LV (c) Physical mixture (d) Solid dispersions prepared by the microwave induced fusion method with an exposure time of $6 \mathrm{~min}$.

\section{Differential scanning calorimetry (DSC)}

DSC thermographs of RLX, HPMC E5 LV, the PM and the SD are presented in Figure 4. The thermograms of RLX and HPMC E5 LV show the respective endothermic peaks corresponding to their melting points, at around

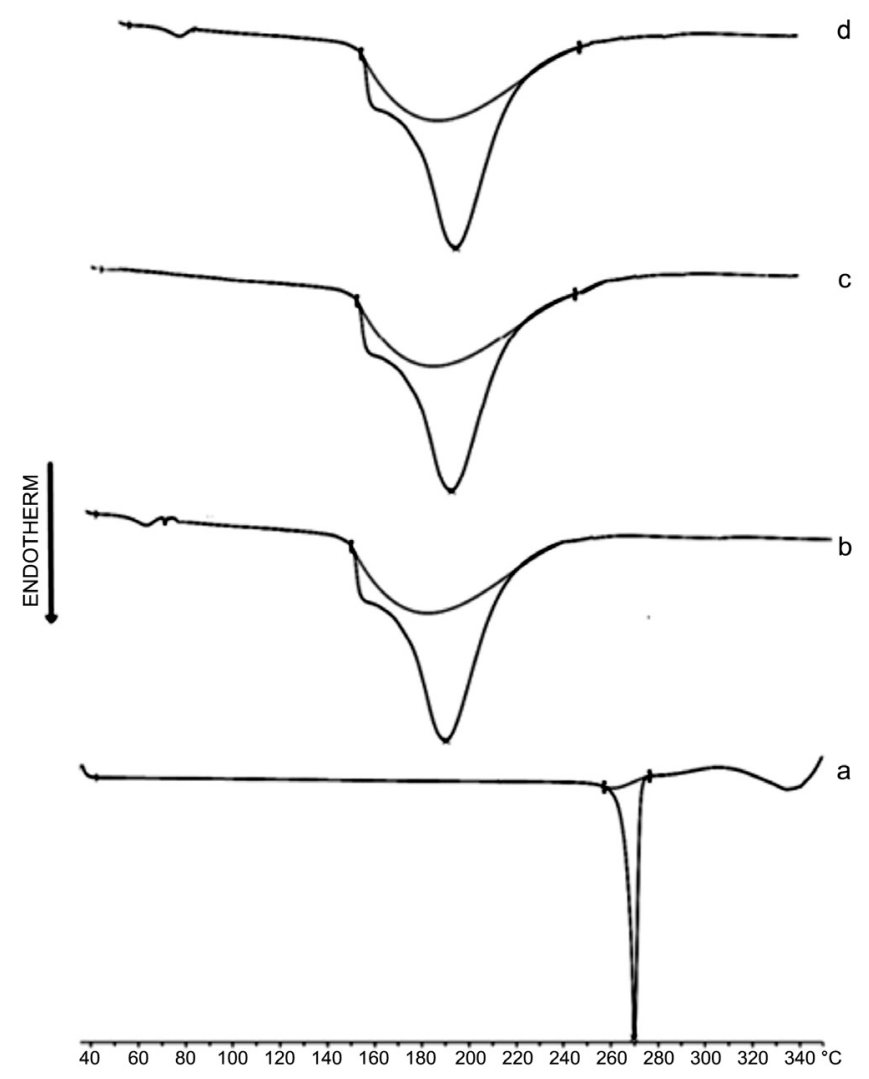

FIGURE 4 - Differential scanning calorimetry curves of (a) Raloxifene $\mathrm{HCl}$ (b) HPMC E5 LV (c) Physical mixture and (d) Solid dispersions prepared by the microwave induced fusion method with an exposure time of 6 min.

$266.44{ }^{\circ} \mathrm{C}$ and $116.75^{\circ} \mathrm{C}$. From the thermograms of the $\mathrm{SD}$ and the PM, it is observed that there is no peak corresponding to the melting point of the drug, suggesting a reduction in crystallinity and the formation of a molecular dispersion of RLX in the SD as well as the PM.

\section{Powder $X$ - ray diffraction (PXRD)}

XRD spectra of RLX, HPMC E5 LV and the SD are presented in Figure 5. XRD studies were performed in conjunction with DSC to verify the reduction in crystallinity of the RLX within the SD. The diffraction spectrum of the drug sample shows distinct peaks at $2 \theta$ values of $12.812^{\circ}, 14.47^{\circ}, 15.784^{\circ}, 19.153^{\circ}, 22.682^{\circ}$ and $25.876^{\circ}$. All these peaks, though of relatively low intensity, are also observed to in the spectrum of the SD. Thus the drug must have been converted from the crystalline state to the amorphous state in the SD.

\section{Scanning Electron Microscopy (SEM)}

The SEM photomicrographs of RLX shown in Figure 6 show longer crystals with a very specific 


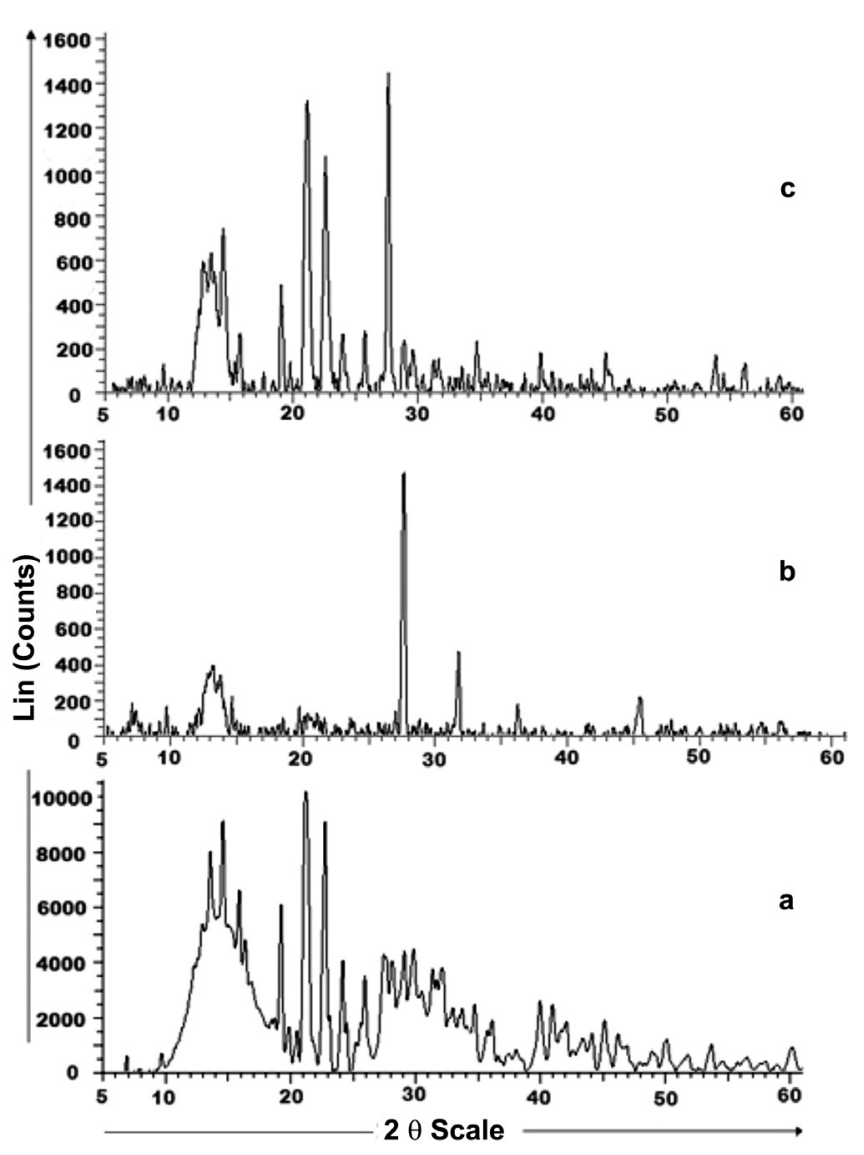

FIGURE 5 - Powder X-ray diffraction patterns (a) Raloxifene $\mathrm{HCl}$, (b) HPMC E5 LV and (c) Solid dispersions prepared by the microwave induced fusion method with an exposure time of $6 \mathrm{~min}$.

morphology. In contrast, in the SDs, a decrease in crystallinity is observed due to molecular dispersion of RLX in the polymer matrix.

\section{Stability Studies}

Stability studies of the formulated solid dispersions were carried out. Various parameters such as the drug content and in vitro release were determined in these studies. There was no colour change after the studies. The in vitro drug release profile of the SD after 120 minutes is shown in Table IV. From the results, it is seen that the solid dispersion is stable at $40{ }^{\circ} \mathrm{C} / 75 \% \mathrm{RH}$.

TABLE IV - Physicochemical evaluation of solid dispersion after stability studies

\begin{tabular}{lcc}
\hline Time (days) & Drug content (\%) & In vitro drug release (\%) \\
\hline 0 & $91.89 \pm 0.70$ & $65.42 \pm 2.68$ \\
30 & $91.23 \pm 0.63$ & $65.01 \pm 1.52$ \\
60 & $91.29 \pm 0.85$ & $64.97 \pm 0.92$ \\
90 & $90.89 \pm 0.42$ & $64.67 \pm 0.89$ \\
\hline
\end{tabular}

All values are Mean \pm S.D., $n=3$

\section{CONCLUSION}

The novelty of this work is the generation of an amorphous system, using the microwave-induced technique that showed a remarkably increased solubility as well as in vitro drug dissolution. Therefore, it is concluded that the use of the microwave-induced fusion method is a promising approach to enhancing the solubility and dissolution rate of RLX, which is poorly soluble in water. The mechanism involved in enhancing the solubility and dissolution rate of RLX in SDs may be attributed to the surfactant and wetting properties of HPMC E5 LV and the formation of molecular dispersions of the drug in the polymer.

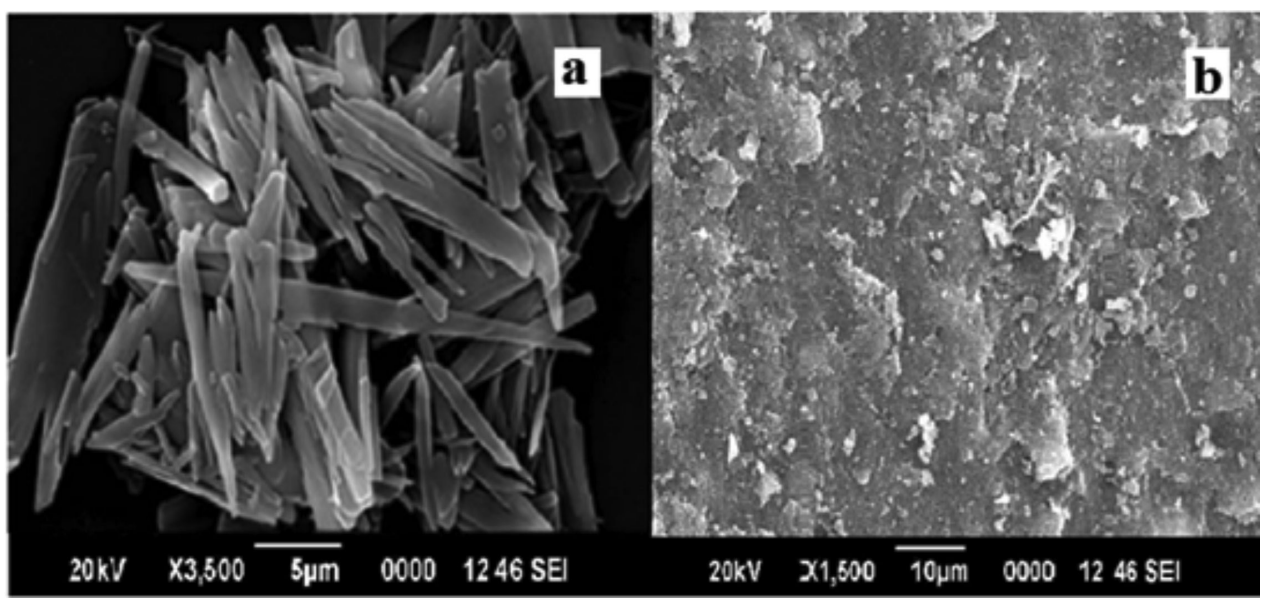

FIGURE 6 - Scanning electron microscopy photographs of (a) Raloxifene $\mathrm{HCl}$ and (b) Solid dispersions prepared by microwave induced fusion method with an exposure time of $6 \mathrm{~min}$. 


\section{ACKNOWLEDGEMENT}

Authors are thankful to Zydus Cadila, Ahmedabad, India and Dow Chemical Company, Midland for providing gift samples of Raloxifene $\mathrm{HCl}$ and $\mathrm{HPMC}$ E5 LV respectively. The authors are thankful to R. C. Patel Institute of Pharmaceutical Education \& Research, Shirpur for providing all necessary facilities to carry out this research work.

\section{REFERENCES}

BOGHRA, R.J.; KOTHAWADE, P.C.; BELGAMWAR, V.S.; NERKAR, P.P.; TEKADE, A.R.; SURANA, S.J. Solubility, Dissolution Rate and Bioavailability Enhancement of Irbesartan by Solid Dispersion Technique. Chem. Pharm. Bull., v.59, p.438-441, 2011.

FEELEY, J.; YORK, P.; SUMBLY, B.; DICKS, H. Determination of surface properties and flow characteristics of salbutamol sulphate before and after micronization. Int. J. Pharm., v.172, p.89-96, 1998.

JHA, R.K.; TIWARI, S.J.; MISHRA, B. Bioadhesive microspheres for bioavailability enhancement of raloxifene hydrochloride: formulation and pharmacokinetic evaluation. AAPS PharmSciTech., v.12, p.651-657, 2011.

KAPPE, C.O. Controlled microwave heating in modern organic synthesis. Angew. Chem. Int. Ed., v.43, p.6250-6284, 2004.

KARANTH, H.; SUBRAYA, V.; RAMACHANDRAMURTHY, R. Industrially feasible alternative approaches in the manufacture of solid dispersions: Technical report. AAPS PharmSciTech., v.7, p.E1-E8, 2006.

KUMAR, A.; SAHOO, S.K.; PADHEE, K.; KOCHAR, P.P.; SATAPATHY, A.; PATHAK, N. Review on solubility enhancement techniques for hydrophobic drugs. Pharmacie Globale Int. J. Compr. Pharm., v.2, p.1-7, 2011.

LIN, C.; DESAI, K.G.H.; LIN, C.; PARK, H.J. Enhancement of dissolution rate of rofecoxib using solid dispersion with urea. Drug Dev. Res., v.63, p.181-189, 2004.

MAURYA, D.B.; BELGAMWAR, V.S.; TEKADE, A.R. Microwave induced solubility enhancement of poorly water soluble atorvastatin calcium. J. Pharm. Pharmacol., v.62, p.1599-1606, 2010.
MOHANACHANDRAN, P.S.; SINDHUMOL, P.G.; KIRAN, T.S. Enhancement of solubility and dissolution rate: an overview. Pharmacie Globale Int. J. Compr. Pharm., v.4, p.1-10, 2010.

MONEGHINI, M.; BELLICH, B.; BAXA, P.; PRINCIVALLE, F. Microwave generated solid dispersions containing Ibuprofen. Int. J. Pharm., v.361, p.125-130, 2008.

MURALI MOHAN BABU, G.V.; PRASAD, CH. D.S.; RAMAN MURTHY, K.V. Evaluation of modified gum karaya as carrier for the dissolution enhancement of poorly water-soluble drug nimodipine. Int. J. Pharm., v.234, p.117, 2002.

NOKHODCHI, A.; TALARI, R.; VALIZADEH, H.; JALALI, M.B., An investigation of the solid dispersion of Chlordizepoxide. Int. J. Biol. Sci., v.3, p.211-217, 2007.

PAPADIMITRIOU, S.A.; BIKIARIES, D.; AVGOUSTAKIS, K. Microwave-induced enhancement of the dissolution rate of poorly water soluble Tibolone from poly (ethylene glycol) solid dispersions. J. Appl. Polym. Sci., v.108, p.1249-1258, 2008 .

PUDIPEDDI, M.; SERAJUDDIN, A.T.M. Trends in solubility of polymorphs. J. Pharm. Sci., v.94, p.929-939, 2005.

RAI, V.K.; RAJPUT, B.; SHARMA, M.; AGARWAL, A.; GUPTA, A.; SINGH, N. Solubility enhancement of poorly water-soluble drug (raloxifene hydrochloride) by using different Hydrophilic binders in solid dosage form. Pharmacie Globale Int. J. Compr. Pharm., v.1, p.1-5, 2010.

SERAJUDDIN, A.T.M. Solid dispersion of poorly water soluble drugs: early promises, subsequent problems and recent breakthroughs. J. Pharm. Sci., v.88, p.1058-1066, 2000.

SHINDE, S.S.; PATIL, S.S.; MEVEKARI, F.I.; SATPUTE, A.S. An approach for solubility enhancement: solid dispersion. Int. J. Adv. Pharm. Sci., v.1, p.299-308, 2010.

WEUTS, I.; KEMPEN, D.; VERRECK, G.; DECORTE, A.; HEYMANS, K.; PEETERS, J.; BREWSTER, M.; MOOTER, G.V. Study of the physicochemical properties and stability of solid dispersion of loperamide and PEG 6000 prepared by spray drying. Eur. J. Pharm. Biopharm., v.59, p.199-126, 2005. 
ZHOU, J.; SHI, C.; MEI, B.; YUAN, R.; FU, Z. Research on the technology and the mechanical properties of the microwave processing of polymer. J. Mater. Process. Technol., v.137, p.156-1582003.

Received for publication on $13^{\text {th }}$ December 2012 Accepted for publication on $16^{\text {th }}$ April 2013 